\title{
[Nitrotyrosyl]Cytochrome $c$
}

\section{STUDIES OF THE EFFECT OF IRON BINDING, PROTEIN DENATURANTS AND OXIDATION-REDUCTION POTENTIALS}

\author{
By AGUINALDO JOSÉ DO NASCIMENTO* \\ School of Biological Sciences, University of East Anglia, Norwich NR4 7TJ, U.K.
}

(Received 24 November 1975)

\begin{abstract}
Static measurements of the reaction of ligand binding were done by conventional spectrophotometry. The ligand-binding reactions with nitrated cytochrome $c$ were performed with imidazole, iminazole, $\mathrm{CO}$ and NO. The stoicheiometry was found to be $1: 1$, and the stability constants for the complexes formed between the nitrated cytochrome $c$ and the ligands are: $2.58 \times 10^{4} \mathrm{M}^{-1}$ (imidazole); $1.01 \times 10^{2} \mathrm{M}^{-1}$ (iminazole); $3.6 \times 10^{4} \mathrm{M}^{-1}(\mathrm{CO}) ; 2.74 \times 10^{4} \mathrm{M}^{-1}(\mathrm{NO})$. It was found that the electrometric potentials at pH7.0 and $25^{\circ} \mathrm{C}$ of [aminotyrosyl]cytochrome $c$ are $E_{0 \text { form II }}^{\prime}=0.115 \mathrm{~V}$ and $E_{0 \text { form I }}^{\prime}=$ $0.260 \mathrm{~V}$, where forms I and II are two species of protein co-existing in the protein solution. The isoelectric point for the oxidized form of [nitrotyrosyl]cytochrome $c$ was 10.05, at $4^{\circ} \mathrm{C}$.
\end{abstract}

Several agents such as $\mathrm{pH}$ and iron ligands displace the haem ligands of [nitrotyrosyl]cytochrome $c$, transforming the protein from a mixed-spin state to a fully high-spin or low-spin configuration (Sokolovsky et al., 1970). The modified protein was interpreted by Schejter et al. (1970) as consisting of two species, derived from the nitration of one of the two positions ortho to the tyrosine-67 hydroxyl group, arising from the fact that the residue is unable to rotate. They refer to these species as form I and form II.

The purpose of the experiments reported here is to investigate some of the physicochemical properties of cytochrome $c$ with tyrosine-67 modified, and analyse the significance of the role played by tyrosine-67 in the structure of native cytochrome $c$.

\section{Materials and Methods}

Native cytochrome $c$ (type III), guanidine and imidazole were obtained from Sigma (London) Chemical Co., Kingston-upon-Thames, Surrey, U.K., and were used without further purification. Iminazole was purchased from BDH, Poole, Dorset, U.K. The concentration of cytochrome $c$ solutions was estimated by using a millimolar extinction coefficient of 27.7 litre $\cdot \mathrm{mmol}^{-1} \cdot \mathrm{cm}^{-1}$ at $550 \mathrm{~nm}$ for the reduced protein (Margoliash, 1954).

[Nitrotyrosyl]cytochrome $c$ was prepared as described by Sokolovsky et al. (1970), and the concentration was estimated at $530 \mathrm{~nm}$ by using a millimolar extinction coefficient of $9.8 \mathrm{litre} \cdot \mathrm{mmol}^{-1} \cdot \mathrm{cm}^{-1}$,

* Present address: Universidade Federal do Paraná, Setor de Ciências Biologicas, Departamento de Bioquímica, Cx. Postal 939, 80.000-Curitiba PR, Brazil. at pH7.0 (Schejter et al., 1970), after addition of solid ferricyanide.

Determination of the isoelectric point was carried out at $4^{\circ} \mathrm{C}$ in an LKB 8101 isoelectric-focusing apparatus (110ml column). Approx. $4 \mathrm{mg}$ of protein was applied to the column and focused in the pH range 9-11 as described by Karlsson \& Ohman (1972). The $\mathrm{pH}$ values of the solutions were measured at $4^{\circ} \mathrm{C}$ by using an EIL pH-meter $23 \mathrm{~A}$, fitted with a Russell microelectrode CMT 21.

Spectrophotometric observations were carried out with a Unicam SP.700A instrument, with a thermostatically controlled compartment. The temperature of the cell compartment was kept constant by water circulation by using a thermostatic bath (Grant Instruments, Cambridge, U.K.). Anaerobic spectrophotometry was carried out in special cuvettes fitted with a vaccine cap. For spectrophotometric titrations, samples of the ligand were added with an Agla micrometer syringe. The volume of the protein solution was measured by weighing the cuvette after the completion of the experiment.

Spectrophotometric observations of the disappearance of the $695 \mathrm{~nm}$ band of [nitrotyrosyl]ferricytochrome $c$ with increasing temperature were analysed by using the assumptions described by Schejter \& George (1964). Results were analysed as a displacement of equilibrium between two conformational isomers, one containing the $695 \mathrm{~nm}$ band ('cold' conformation) and the other lacking this band ('hot' conformation). The molar extinction coefficient at $695 \mathrm{~nm}$ at $\mathrm{pH} 4.5$ for the [nitrotyrosyl]ferricytochrome $c\left[\left(\varepsilon_{695}\right)_{c}\right]$ was calculated to be 600 litre $\cdot \mathrm{mol}^{-1} \cdot \mathrm{cm}^{-1}$ at $10^{\circ} \mathrm{C}$ for the 'cold' conformation and 439 litre $\cdot \mathrm{mol}^{-1} \cdot \mathrm{cm}^{-1}$ in $6 \mathrm{M}$-guanidine 
at the same temperature for the 'hot' conformation [( $\left.\left.\varepsilon_{695}\right)_{\mathrm{h}}\right]$.

Gases were supplied by British Oxygen Company, Deer Park Road, London S.W.19, U.K., except for NO, which was supplied by Matherson Gas Products, East Rutherford, NJ, U.S.A. $\mathrm{N}_{2}$ and $\mathrm{CO}$ were stored in glass vessels under alkaline dithionitereduced anthraquinone solution.

Measurements of electrometric potentials were carried out under anaerobic conditions in a jacketed glass vessel, adequate for titration of a $15 \mathrm{ml}$ sample. All measurements were made at $25 \pm 1^{\circ} \mathrm{C}$. Potassium ferricyanide (obtained from Hopkin and Williams, Chadwell Heath, Essex, U.K.) was used as oxidant and was added to the vessel with an Agla micrometer syringe. Stirring was effected with a Teflon-coated magnetic bar and an immersible magnetic stirrer (Rank Brothers, Cambridge, Cambs., U.K.). The reaction medium contained about a $3.0 \mu \mathrm{M}$ solution of buffered [nitrotyrosyl]cytochrome c. Constant $\mathrm{H}^{+}$ion concentration during the electrometric titration was maintained by means of sodium acetate buffer (pH5.5-5.8), sodium phosphate buffer (pH 6.0-7.8), Tris/HCl buffer (pH8.0-9.0) and glycine/ $\mathrm{NaOH}$ buffer (pH9.2-9.5). The total ionic strength of the reaction medium was kept below $0.006 \mathrm{~mol} / \mathrm{litre}$ to remain in the Debye-Huckel region (any residual junction potential in the region of very low ionic strength is either insignificantly small or is virtually constant). The protein was fully reduced before the titration by adding a freshly prepared solution of dithionite $(10 \mathrm{mg} / \mathrm{ml}$ ) (obtained from Hardman \& Holden, Manchester, U.K.). Then $10 \mu 1$ of the mediator $N N N^{\prime} N^{\prime}$-tetramethyl-pphenylenediamine was added to give a concentration of $8.0 \mu \mathrm{M}$ (final concentration).

Potentiometric measurements were made between a platinum electrode (Radiometer P101) and a calomel electrode (Radiometer K 401), by using a Radiometer pH-meter 51B. Equilibrium potential values $\left(E_{\mathrm{h}}\right)$ were obtained at $10 \mathrm{~min}$ intervals after addition of the titration agent. Titration was monitored by direct-vision spectroscopy, by using a Hartridge Reversion Spectroscope (Beck, London, U.K.).

$\mathrm{O}_{2}$-free $\mathrm{N}_{2}$ was further purified by passage through two wash bottles fitted with sintered-glass discs and filled with $\mathrm{Cr}^{2+}$ solution $\left(\mathrm{CrCl}_{2}\right)$ over granulated zinc. Before an experiment, the titration vessel and contents were thoroughly flushed free of $\mathrm{O}_{2}$.

\section{Results}

Effect of guanidine hydrochloride and temperature on the 695 and $612 \mathrm{~nm}$ band

Fig. 1 represents the spectra of [nitrotyrosyl]ferricytochrome $c$ recorded at $10^{\circ}$ and $45^{\circ} \mathrm{C}$ in the region of 612 and $695 \mathrm{~nm}$. Similar behaviour is observed on addition of guanidine hydrochloride to [nitrotyrosyl]ferricytochrome $c$, as shown in Fig. 2, as the high-spin $620 \mathrm{~nm}$ band appears at full strength on the type I denatured conformation. Fig. 3 shows the effect of temperature on the $E_{695}$ of [nitrotyrosyl]ferricytochrome $c$. The plot of the log of absorbance
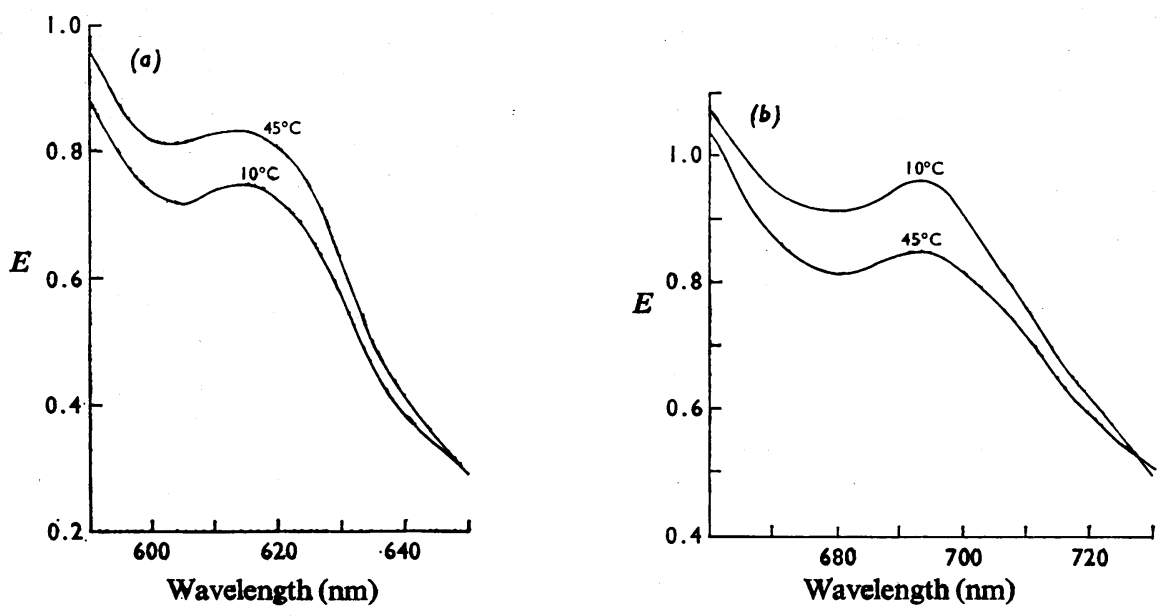

Fig. 1. Spectra of [nitrotyrosyl] ferricytochrome c at $10^{\circ}$ and $45^{\circ} \mathrm{C}$ recorded in the region of 612 and $695 \mathrm{~nm}$

(a) Spectra recorded at two temperatures in the region of $612 \mathrm{~nm}$ with $0.344 \mathrm{~mm}$-[nitrotyrosyl]ferricytochrome $c$. (b) Spectra recorded at two temperatures in the region of $695 \mathrm{~nm}$ with $1.456 \mathrm{~mm}$-[nitrotyrosyl]cytochrome $c$. The buffer used was 0.1 M-sodium acetate, pH4.5. 

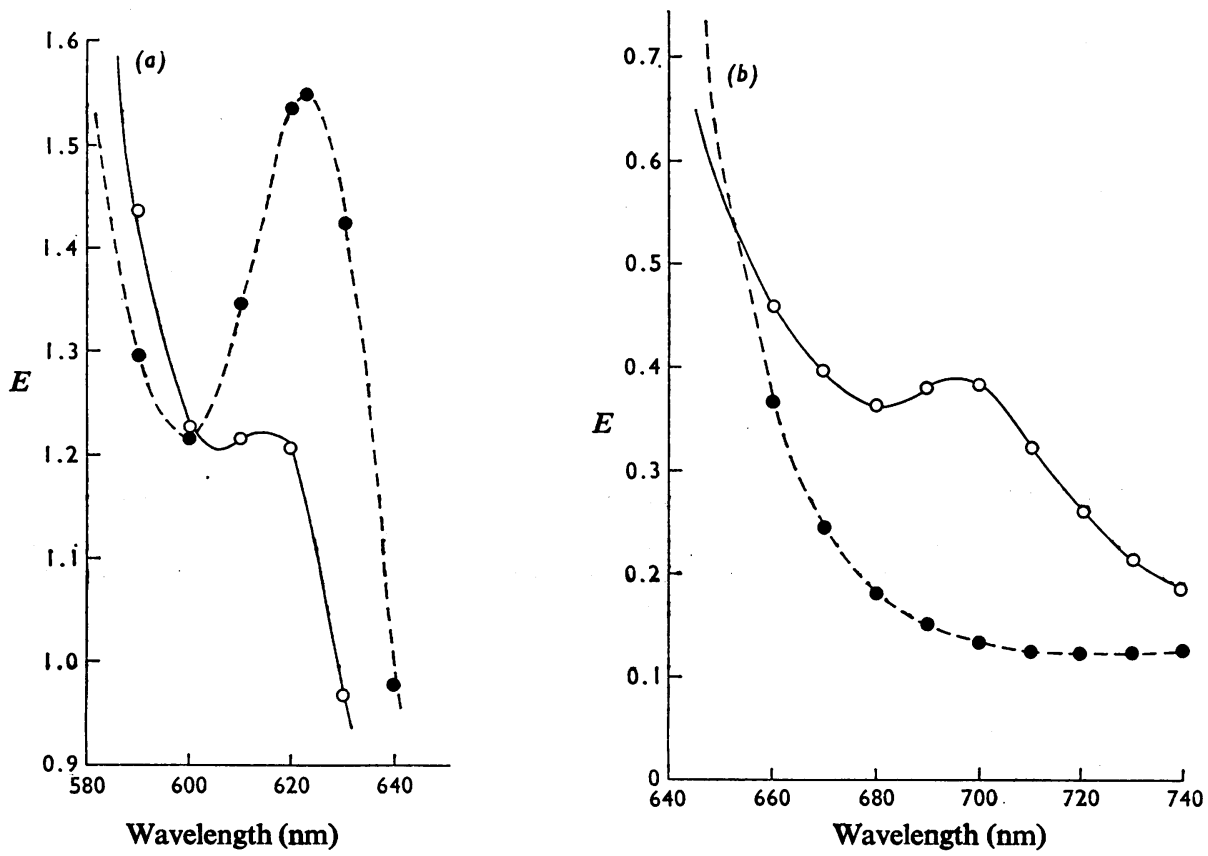

Fig. 2. Effect of guanidine on the 612 and $695 \mathrm{~nm}$ band of [nitrotyrosyl] ferricytochrome $\mathrm{c}$

(a) Spectra recorded in the region of $612 \mathrm{~nm}$. (b) Spectra recorded in the region of $695 \mathrm{~nm}$. [Nitrotyrosyl]ferricytochrome $c$ was used in this experiment at $0.580 \mathrm{~mm}$. The buffer used was $0.1 \mathrm{M}$-sodium acetate, $\mathrm{pH} 4.5$. $\bigcirc$, Native protein; $\bullet$, protein in $4.3 \mathrm{M}$-guanidine. The temperature was $10^{\circ} \mathrm{C}$.

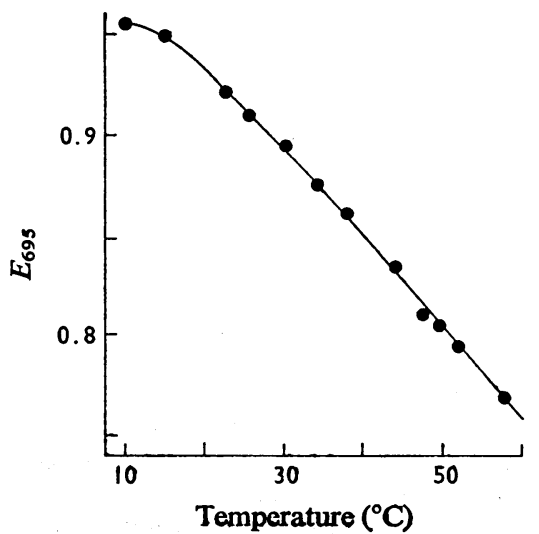

Fig. 3. Effect of temperature on the absorbance of the $695 \mathrm{~nm}$ band of [nitrotyrosyl] ferricytochrome $c$

The protein concentration was $1.456 \mathrm{~mm}$. The experiment was performed in $0.1 \mathrm{M}$-sodium acetate buffer, $\mathrm{pH} 4.5$. The temperature was gradually increased from $10^{\circ}$ to $60^{\circ} \mathrm{C}$.

change versus reciprocal of temperature is shown in Fig. 4. The plot is linear for the interval $22-57.5^{\circ} \mathrm{C}$, and the thermodynamic parameters evaluated for this temperature-dependent isomerism at $26^{\circ} \mathrm{C}$ are

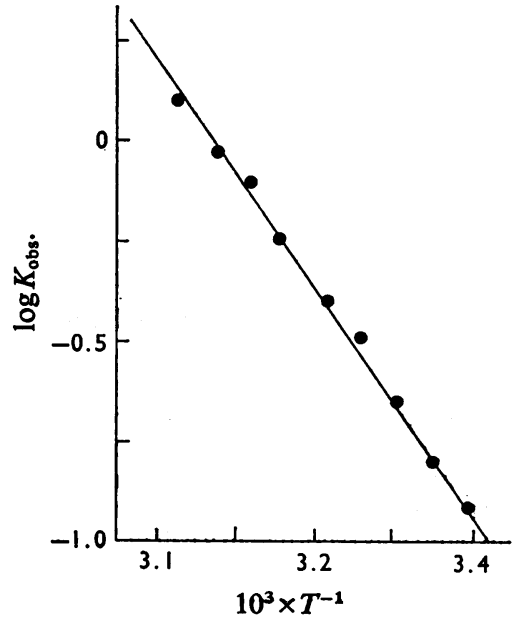

Fig. 4. Van't Hoff plot for the data of Fig. 3

Plot of the $\log K_{\text {obs. }}$ versus $T^{-1}$ for the reaction [nitrotyrosyl]ferricytochrome $c$ 'cold' $\leftrightarrow$ [nitrotyrosyl]ferricytochrome $c$ 'hot', by the equation

$$
K_{\text {obs. }}=\frac{\left(E_{695}\right)_{t}-\left(E_{695}\right)_{c}}{\left(E_{695}\right)_{1}-\left(E_{695}\right)_{t}}
$$

of Fig. 3 (see the text for details).

Vol. 155 


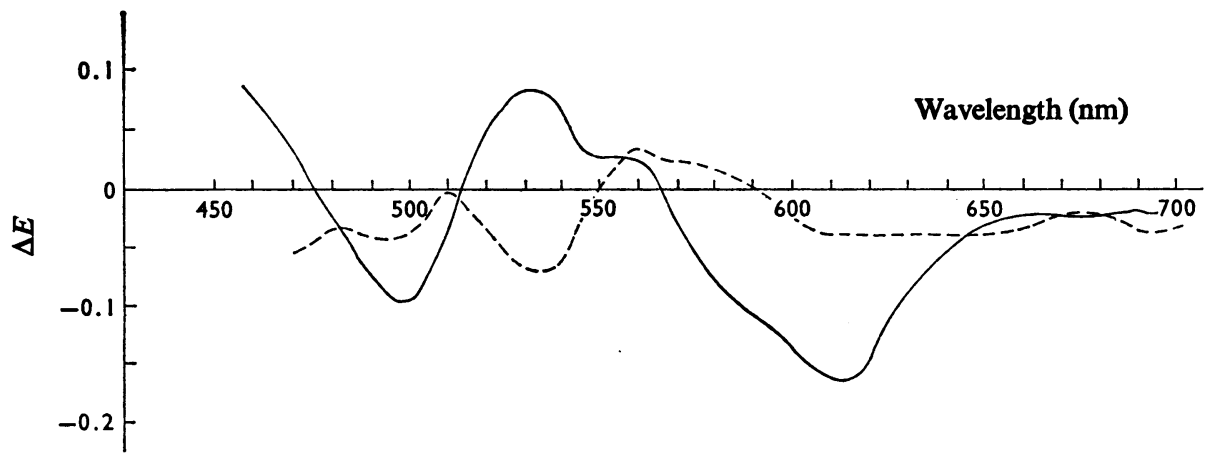

Fig. 5. Difference spectra of ferricytochrome $c$ and ferricytochrome c-imidazole complex

Nitrated and native ferricytochrome $c(0.112 \mathrm{mM}$, after mixing) was treated with $1.0 \mathrm{M}$-imidazole (final concn. after mixing).

Modified protein; --_-, native cytochrome $c$. The experiments were performed in 0.1 M-sodium phosphate buffer, pH7.0. The reference cell was made $1.0 \mathrm{M}$ with $\mathrm{NaCl}$ to give a constant ionic strength.
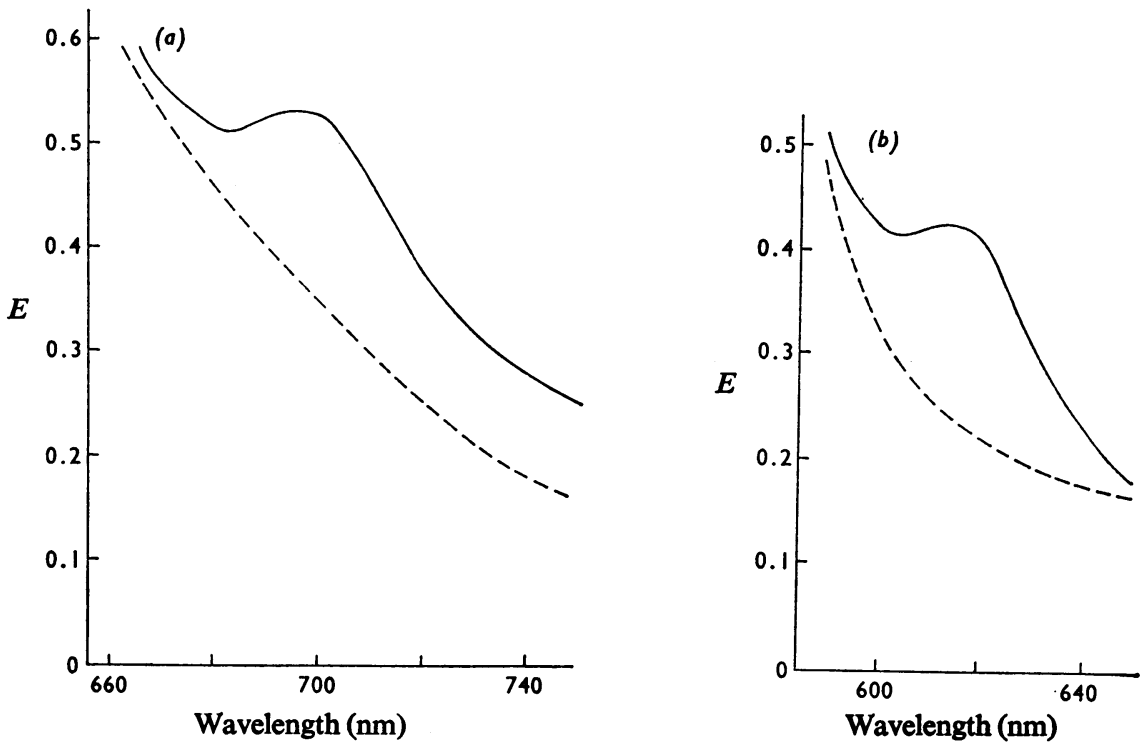

Fig. 6. Effect of iminazole on the 612 and $695 \mathrm{~nm}$ bands

(a) Spectra of [nitrotyrosyl]ferricytochrome $c(-)$ and [nitrotyrosyl]ferricytochrome $c$-iminazole complex (----), recorded in the region of $695 \mathrm{~nm}$. (b) Spectra of [nitrotyrosyl]ferricytochrome $c(-)$ and [nitrotyrosyl]ferricytochrome $c-$ iminazole complex (---) recorded in the region of $612 \mathrm{~nm}$. The protein $(0.790 \mathrm{~mm}$, final concn. after mixing) was treated with 0.136 M-iminazole (final concn. after mixing). The experiments were performed in 0.1 M-sodium acetate buffer, pH4.5. The $695 \mathrm{~nm}$ band was recorded in a cell of $2 \mathrm{~cm}$ light-path, and the $612 \mathrm{~nm}$ band was recorded in a cell of $1 \mathrm{~cm}$ path-length.

$\Delta G^{0}=4.58 \pm 0.42 \mathrm{~kJ} \cdot \mathrm{mol}^{-1}, \quad \Delta H^{0}=54.46 \pm 1.17 \mathrm{~kJ}$. $\mathrm{mol}^{-1}$ and $\Delta S^{0}=167.36 \pm 2.09 \mathrm{~kJ} \cdot \mathrm{mol}^{-1} \cdot{ }^{\circ} \mathrm{C}^{-1}$.

\section{Effect of imidazole and iminazole}

On addition of imidazole to [nitrotyrosyl]ferricytochrome $c$ at pH7.0 a low-spin conformation is obtained, as evidenced by the disappearance of the
$612 \mathrm{~nm}$ band and enhancement of the $530 \mathrm{~nm}$ band (Fig. 5). We observed that the closely related compound iminazole can bind the protein at $\mathrm{pH} 4.5$, and the effects of this ligand on the $695 \mathrm{~nm}$ band of the low-spin conformation and the $612 \mathrm{~nm}$ band of the high-spin conformation are shown in Fig. 6.

The spectrophotometric titration of [nitrotyrosyl]ferricytochrome $c$ with imidazole (pH7.0) and imin- 


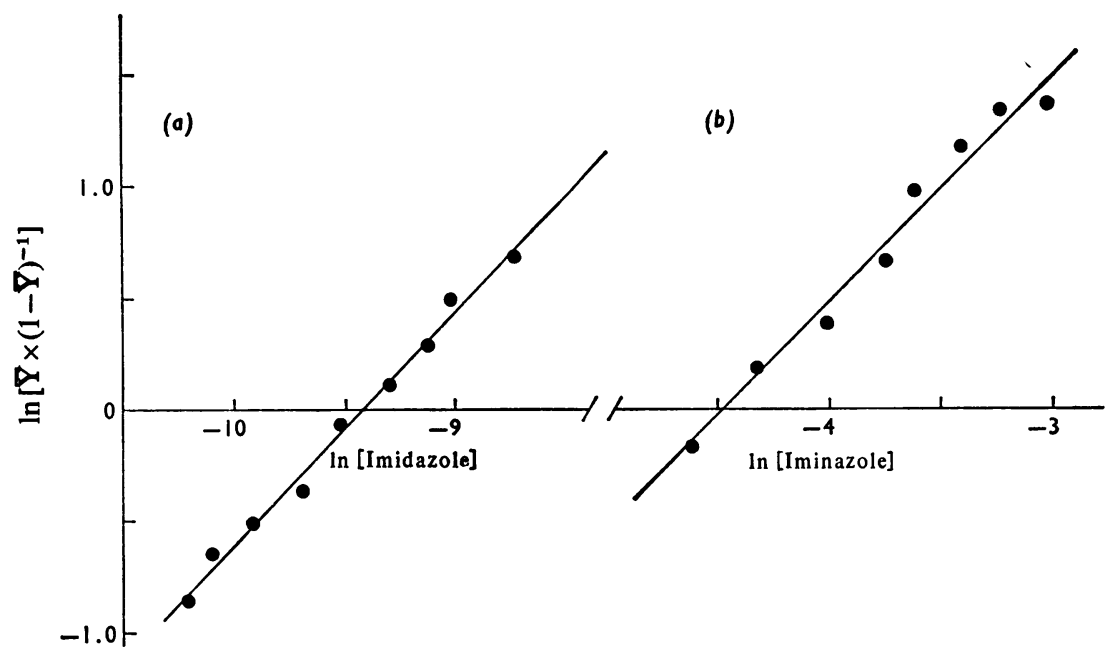

Fig. 7. Hill plot of the titration of [nitrotyrosyl]ferricytochrome c with imidazole (a) and iminazole (b)

Plot of $\ln (\overline{\mathbf{Y}}) / \ln (1-\overline{\mathbf{Y}})$ versus $\ln$ [imidazole] or $\ln$ [iminazole], where $\overline{\mathbf{Y}}$ represents the fraction of site-occupied protein. [Nitrotyrosyl]ferricytochrome $c(0.791 \mathrm{mM})$ was titrated with $1.22 \mathrm{M}$ solutions of imidazole or iminazole. The imidazole titration $(a)$ was performed in $0.1 \mathrm{M}$-sodium phosphate buffer, $\mathrm{pH} 7.0$, at $604 \mathrm{~nm}$. The iminazole titration $(b)$ was performed in $0.1 \mathrm{M}$-sodium acetate buffer, $\mathrm{pH} 4.5$, at $695 \mathrm{~nm}$.

Table 1. Affinity constants for the reaction of [nitrotyrosyl]cytochrome $c$ and cytochrome $c$ with ligands

Affinity constants were determined from plots of $\ln (\overline{\mathbf{Y}}) /$ $\ln (1-\bar{Y})$ versus $\ln (\mathbf{S})$, where $\mathbf{Y}$ represents the fraction of the site-occupied protein and $S$ represents the concentration of ligand added. The buffers used were sodium acetate buffer, $\mathrm{pH} 4.5$, sodium phosphate buffer, $\mathrm{pH}$ 6-7, $\mathrm{Na}_{2} \mathrm{CO}_{3} / \mathrm{NaHCO}_{3}, \mathrm{pH} 10$, and ionic strength of $0.1 \mathrm{~mol} /$ litre. The values are means of four determinations.

[Nitrotyrosyl]cytochrome $c$

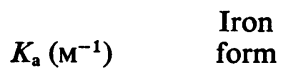

Imidazole (pH7)

Iminazole (pH4.5)

$\mathrm{CO}(\mathrm{pH} 10)$

$\mathrm{CO}$ (pH6)

NO (pH10)

Native cytochrome $c$

Imidazole ( $\mathrm{pH} 7)$

Iminazole (pH4.5)
$2.58 \times 10^{4} \pm 0.02 \times 10^{4}$ Ferric

$1.01 \times 10^{2} \pm 0.09 \times 10^{2}$ Ferric

$1.40 \times 10^{4} \pm 0.06 \times 10^{4}$ Ferrous

$2.74 \times 10^{4} \pm 0.05 \times 10^{4}$ Ferrous

$2.74 \times 10^{4} \pm 0.05 \times 10^{4}$ Ferrous

$$
\begin{aligned}
18.97 \pm 0.31 & \text { Ferric } \\
0.91 \pm 0.07 & \text { Ferric }
\end{aligned}
$$

azole (pH4.5) are shown as a Hill plot in Fig. 7. Only unprotonated imidazole as a ligand of cytochrome $c$ (Schejter \& Aviram, 1969). At pH 7.0, the ratio of protonated imidazole to unprotonated species is 1.06 . This value was used to calculate the concentration of unprotonated imidazole and the value of the equilibrium constant in Table 1 .

\section{Effect of $\mathrm{CO}$}

Fig. 8 illustrates the difference spectra of the [nitrotyrosyl]ferrocytochrome c-CO complex and [nitrotyrosyl]ferrocytochrome $c$ at various $\mathrm{pH}$ values and at constant concentration of protein and CO. Fig. 9 illustrates the Hill plot for the spectrophotometric titration of [nitrotyrosyl]ferrocytochrome $c$ with $\mathrm{CO}$ solution, at $410 \mathrm{~nm}$. The equilibrium constant calculated from Fig. 9 is listed in Table 1.

\section{Effect of NO}

Spectrophotometric titration of [nitrotyrosyl]ferrocytochrome $c$ with NO was performed at alkaline $\mathrm{pH}$ at $550 \mathrm{~nm}$. The equilibrium constant estimated from Fig. 10 is listed in Table 1.

\section{Oxidation-reduction potential}

Dithionite reduces the nitro group of the tyrosine to the amino group very rapidly (Sokolovsky et al., 1966). Therein, the dithionite-reduced [nitrotyrosyl]cytochrome $c$ is called [aminotyrosyl]cytochrome $c$.

The electrometric data were analysed graphically to estimate the potential at $50 \%$ oxidation of the protein, as illustrated in Fig. 11, when two values were obtained for each titration, because of the two forms of modified protein that co-exist in solution (form I and form II). The standard reduction potential values 


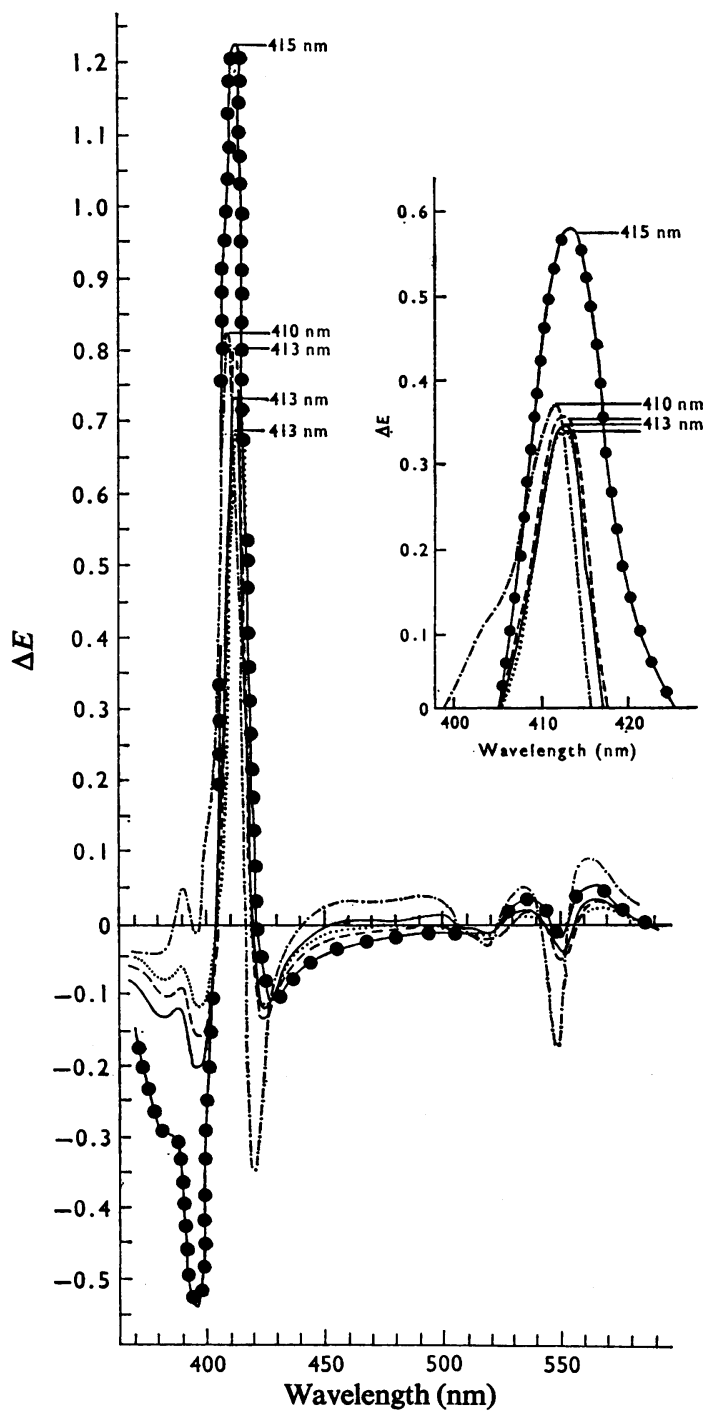

Fig. 8. Difference spectra of [nitrotyrosyl] ferrocytochrome c and [nitrotyrosyl] ferrocytochrome c-CO complex, as function of $\mathrm{pH}$

[Nitrotyrosyl]ferrocytochrome $c(17.3 \mu \mathrm{M})$ was incubated with saturated $\mathrm{CO}$ at room temperature. The protein was reduced in the absence of air with excess of ascorbate. The experiment was carried out in a Thunberg-type cuvette $(1 \mathrm{~cm}$ light-path). The inset shows an experiment carried out with $8.2 \mu \mathrm{M}$-[nitrotyrosyl]ferrocytochrome $c$. - pH2.1 in $0.1 \mathrm{M}$-glycine/HCl buffer;,$- \mathrm{pH} 4.5$ in $0.1 \mathrm{M}$-sodium acetate buffer; - -, pH6.0 in $0.1 \mathrm{M}-$ sodium phosphate buffer; -..., pH10.1 in 0.1 M-glycine/ $\mathrm{NaOH}$ buffer; $\cdots, \mathrm{pH} 7.0$ in sodium phosphate buffer.

for [aminotyrosyl]cytochrome $c$ was determined to be $+115 \mathrm{mV}$ for the larger fraction (form II) and $+260 \mathrm{mV}$ for form I, at $\mathrm{pH} 7$ and $25^{\circ} \mathrm{C}$.

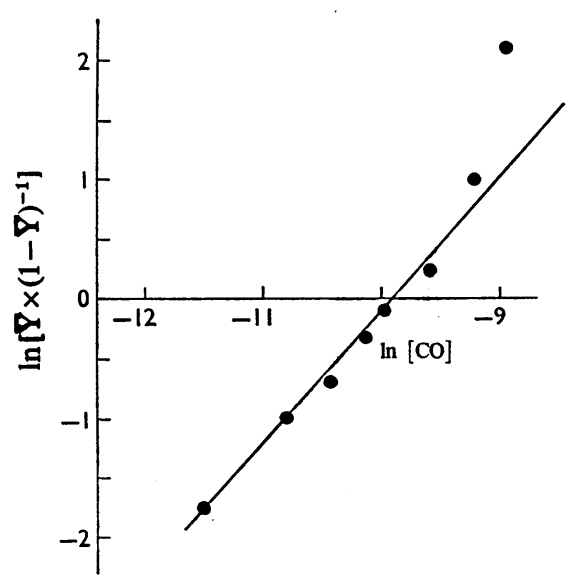

Fig. 9. Hill plot for the titration of [nitrotyrosyl]ferrocytochrome $c$ with $\mathrm{CO}$

[Nitrotyrosyl]ferrocytochrome $c(5.09 \mu \mathrm{M})$ was titrated with $1 \mathrm{~mm}$ solution of $\mathrm{CO}$. The experiment was carried out in $0.1 \mathrm{M}-\mathrm{Na}_{2} \mathrm{CO}_{3} / \mathrm{NaHCO}_{3}$ buffer, pH10.0. The protein was reduced with excess of ascorbate. The reaction was observed at $410 \mathrm{~nm}$.

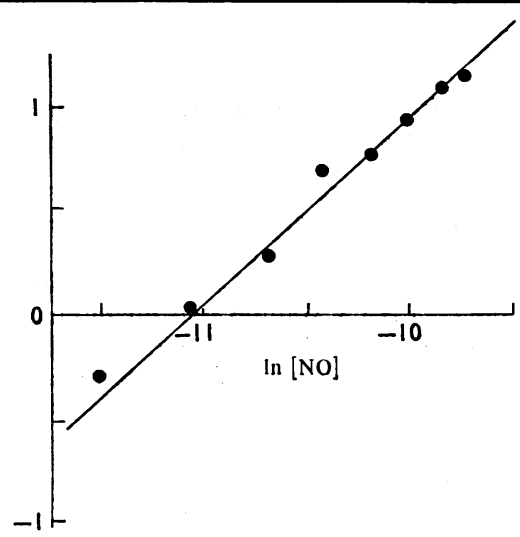

Fig. 10. Hill plot for the titration of [nitrotyrosyl]ferrocytochrome $c$ with NO

Plot of $\ln (\bar{Y}) / \ln (1-\bar{Y})$ versus $\ln (\mathrm{NO})$, where $\bar{Y}$ represents the fraction of site-occupied protein. [Nitrotyrosyl]cytochrome $c$ (ferrous form) was titrated with a $2.06 \mathrm{~mm}$ solution of NO. The buffer used was $0.1 \mathrm{M}-\mathrm{Na}_{2} \mathrm{CO}_{3} /$ $\mathrm{NaHCO}_{3}, \mathrm{pH} 10.0$. The protein was reduced with excess of ascorbate. The reaction was monitored at $550 \mathrm{~nm}$.

The oxidation-reduction potentials at $25^{\circ} \mathrm{C}$ through the pH range 5.5-9.5 are given in Fig. 12. The potential at $25^{\circ} \mathrm{C}$, in the linear portion of the dependence curve varies with $\mathrm{pH}$ according to the equation:

$$
\frac{\Delta E_{0}}{\Delta \mathrm{pH}}=\frac{-0.059 \times a}{n}
$$


where $E_{0}$ represents the standard reduction potential, $a$ the number of $\mathrm{H}^{+}$ions released in the oxidation reaction and $n$ the number of electrons involved in the process(Fruton \& Simmonds, 1963). The titration performed spectrophotometrically shows clearly that $n=1$ for the cytochrome $c$-ferricyanide system (Hawkridge \& Kuwana, 1973). The values for the slope, $\mathrm{p} K$ and $a$ calculated from Fig. 12 are listed in Table 2.

\section{Determination of the isoelectric point}

The isoelectric point of the [nitrotyrosyl]cytochrome $c$ was determined to be 10.05 at $4^{\circ} \mathrm{C}$ (Fig. 13). During the electrofocusing experiments, the native molecule is gradually reduced, until it is fully reduced

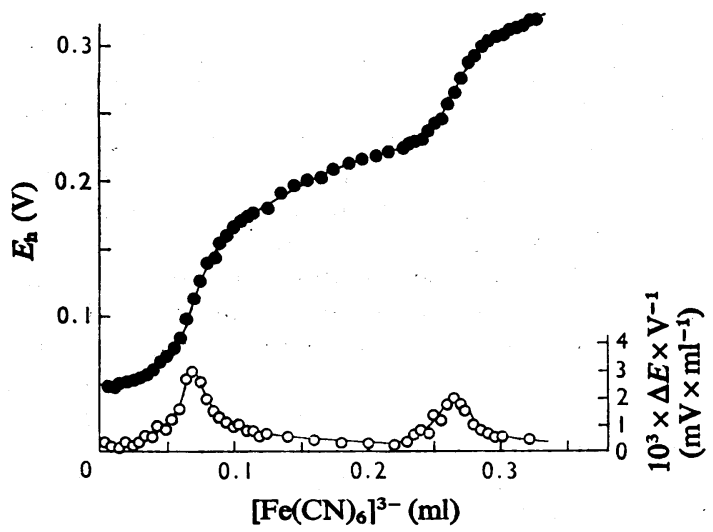

Fig. 11. A typical potentiometric titration curve obtained for the [aminotyrosyl]cytochrome c system

Plot of the equilibrium potential values $\left(E_{\mathrm{h}}\right)$ versus $\left[\mathrm{Fe}(\mathrm{CN})_{6}\right]^{3-}$. [Aminotyrosyl]ferrocytochrome $c(3.0 \mu \mathrm{M})$ was titrated with $1 \mathrm{~mm}$-potassium ferricyanide. The iron and the nitro group of the protein was reduced with excess of dithionite. The buffer used was $0.002 \mathrm{M}$-sodium phosphate, pH7.0. $\bullet$, Potentiometric curve; $\bigcirc$, firstderivative curve. The results yield standard reduction potential of $0.115 \mathrm{~V}$ for the larger fraction (form II) and $0.260 \mathrm{~V}$ for the smaller fraction (form I). at the end of the run. Unlike the native protein, the [nitrotyrosyl]cytochrome $c$ is not reduced during the experiment, and its pI value reported here corresponds to the ferric form.

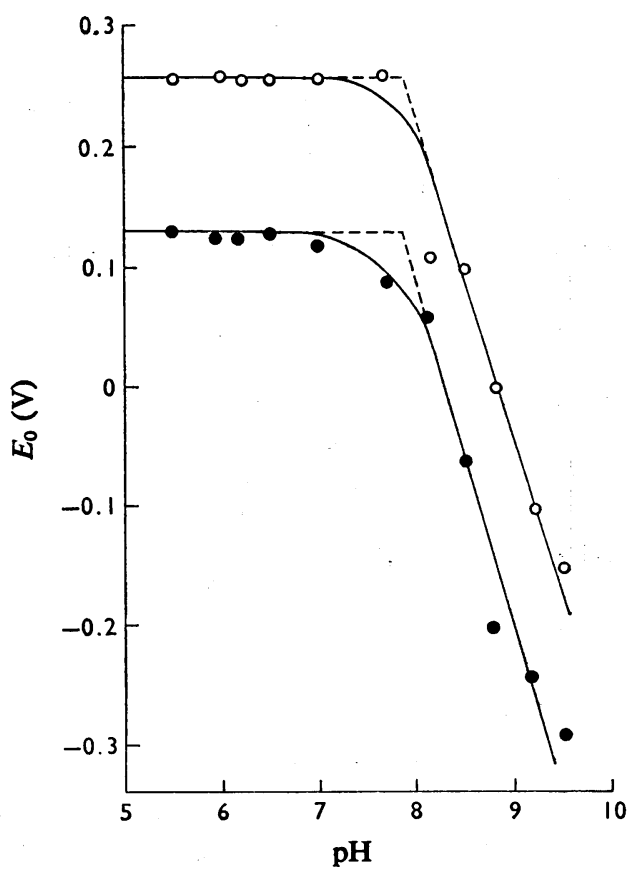

Fig. 12. Observed standardredox potentialof [aminotyrosyl]cytochrome c between pH5.5 and 9.5

The solid line was calculated from the formula:

$$
E_{0}=E_{\mathrm{m}}+\frac{0.059 a}{n} \times \ln \frac{\left[\mathrm{H}^{+}\right]}{\left[\mathrm{H}^{+}\right]+K}
$$

-, Larger fraction (form II) with $E_{\mathrm{m}}=+0.115 \mathrm{~V}, a=4.23$ and $K=1.58 \times 10^{-8} \mathrm{M}$. $\bigcirc$, Smaller fraction (form I) with $E_{\mathrm{h}}=+0.260 \mathrm{~V}, a=3.89$ and $K=1.58 \times 10^{-8} \mathrm{M} . E_{0}$ represents the observed standard potential. The buffers used were sodium phosphate buffer (pH6-7.8), Tris/HCl buffer (pH8-9) and glycine/ $\mathrm{NaOH}$ buffer, (pH9.2-9.5). Measurements were made at $25^{\circ} \mathrm{C}$ and an ionic strength of $0.002 \mathrm{~mol} / \mathrm{litre}$.

Table 2. Values of the variation of the potential for unit $p H$ decrease $\left(\Delta E_{0} / \Delta p H\right)$, number of $H^{+}$released $(a)$ and the $p K$ of ionization in the process, at alkaline $\mathrm{pH}$

Constants were calculated from slope and point of intersection of the plots of $E_{0}$ versus pH (eqn. 1). Measurements were made at $25^{\circ} \mathrm{C}$ and an ionic strength of $0.002 \mathrm{~mol} /$ litre. The buffers used were sodium phosphate buffer (pH6-7.8), Tris/HCl buffer (pH8.0-9.0) and glycine/ $\mathrm{NaOH}$ buffer $(\mathrm{pH} 9.2-9.5)$. The values for unit $\mathrm{pH}$ decrease are means of four determinations.

[Aminotyrosyl]cytochrome $c$, form I [Aminotyrosyl]cytochrome $c$, form II Native cytochrome $c$

$$
\left(\Delta E_{0} / \Delta \mathrm{pH}\right)
$$

$0.229 \pm 0.031$

$0.250 \pm 0.023$

0.06 a

3.89

4.23

1 $\mathrm{p} K$

7.8

7.8

7.8
This work

This work

Rodkey \& Ball (1950) 


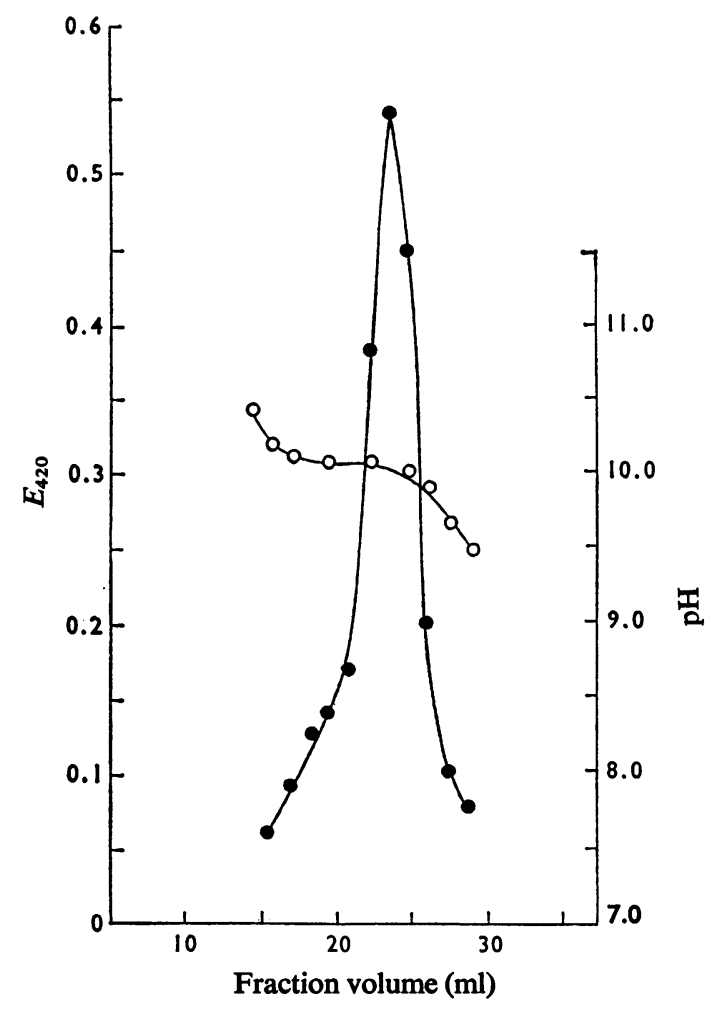

Fig. 13. Results of analysis of fractions from the iso-electricfocusing experiment for [nitrotyrosyl] ferricytochrome $c$

Approx. $4 \mathrm{mg}$ of protein was applied to the column. Sorbitol was used as stabilizing medium. [Nitrotyrosyl]ferricytochrome $c$; $\mathrm{O}, \mathrm{pH}$ of the fraction at $4^{\circ} \mathrm{C}$. The results yield an isoelectric point of 10.05 at $4^{\circ} \mathrm{C}$.

\section{Discussion}

The conformational change of [nitrotyrosyl]cytochrome $c$ observed at $695 \mathrm{~nm}$ on increasing the temperature is accompanied by a more favourable enthalpy change than for the native protein, and an equally high entropy change. The enthalpy change is lowered by about $6.7 \mathrm{~kJ} / \mathrm{mol}$ on nitration of cytochrome $c$.

No haem protein exists in the low-spin form without two strong ligands co-ordinated to the iron (Zerner et al., 1966), and the imidazole and iminazole experiments can be interpreted as the ligand replacing the sixth ligand in the form I configuration of [nitrosyl]cytochrome $c$, and replacing water as the fifth and sixth ligands and pushing the iron into the porphyrin plane in the form II configuration of [nitrotyrosyl]cytochrome $c$. The reaction can be illustrated as

$$
\begin{aligned}
& \mathrm{His}-\mathrm{Fe} \text { (III)-L }+\mathrm{Im} \rightleftharpoons \mathrm{His}-\mathrm{Fe}(\mathrm{III})-\mathrm{Im} \text { (form I) } \\
& \mathrm{H}_{2} \mathrm{O}-\mathrm{Fe} \text { (III)- } \mathrm{H}_{2} \mathrm{O}+\mathrm{Im} \rightleftharpoons \mathrm{His}-\mathrm{Fe}(\mathrm{III})-\mathrm{Im} \text { (form II) }
\end{aligned}
$$

where L represents the unknown fifth ligand, and Im represents the added ligand.

The nitration of cytochrome $c$ confers on the protein a marked pH-dependence, which seems to be the result of a weak stability of the protein conformation. The protein is very unstable at low ionic strength. Dialysis against glass-distilled water makes the nitrated protein very insoluble. Further, if the protein is forced to assume a high-spin configuration by either being submitted to a strongly acidic environment or adding guanidine hydrochloride the completely denaturated blue-shifted protein is obtained.

The shift of the Soret peak (blue shift) of native cytochrome $c$ has been known for a long time. Several workers have observed the shift under a variety of conditions (Theorell \& Åkesson, 1941b; Boeri et al., 1953; Stellwagen, 1967; Kaminsky \& Davison, 1969; Myer, 1968; Wilson, 1970). However, the effect of the blue shift on the colour of the native cytochrome $c$ is only to bleach the red colour.

The amount of protein reduced by ascorbate below pH7.0 remains approximately constant, and it seems clear from Fig. 8 that the spectrum of [nitrotyrosyl]ferrocytochrome $c-\mathrm{CO}$ complex is also pH-dependent. If the protein is made fully reduced by addition of dithionite or $\mathrm{Cr}^{2+}$, the reaction with $\mathrm{CO}$ is improved but the extinction coefficients of the $\mathrm{CO}$ compound, at their extinction maxima, are lower than the values obtained for more drastic modifications of cytochrome $c$ (see, e.g., Tsou, 1951; Brunori et al., 1973).

The value of $a$ corresponds closely to four (Table 2). It can be inferred that the alkaline proton-linked conformational change of [aminotyrosyl]cytochrome $c$ involves the liberation of four $\mathrm{H}^{+}$ions. The native molecule has one proton linked with the alkaline conformational change, although two protons are believed to be associated with the conformational change taking place at $\mathrm{pH}$ values lower than 1.75 (Rodkey \& Ball, 1950).

The proton-linked conformational changes at alkaline $\mathrm{pH}$, from studies performed on alkylated cytochrome $c$, have been associated with the lysine-79 residue (Brunori et al., 1973) and the histidine-18 residue (Aviram \& Krauss, 1974).

The participation of tyrosine-67 in the alkaline conformation change has been suggested by Salemme et al. (1973). The presently available information does not help us to understand this process, but the nitration of tyrosine-67 not only lowers the $\mathrm{pK}$ of transition of type II to type IV cytochrome $c$ (Skov \& Williams, 1971), but also increases the apparent number of protons liberated in the alkaline conformation to four and decreases the isoelectric point of cytochrome $c$ from 10.6 to 10.05 at $4^{\circ} \mathrm{C}$ (Fig. 13) (Theorell \& Åkesson, 1941a).

Fig. 12 shows that both form I and form II con- 
figurations of [aminotyrosyl]cytochrome $c$ undergo ionization at alkaline $\mathrm{pH}$, followed by a change in conformation to a form with much lower redox potential. The redox potential at $\mathrm{pH} 9.5$ for the major fraction (form II configuration) was determined to be $-290 \mathrm{mV}$ (Fig. 12). This value is similar to the $E_{0}$ values obtained for enzyme-digested haemopeptide cytochrome $c$ (Minakami et al., 1957; Harbury \& Loach, 1960).

I thank the British Council for a fellowship, Dr. C. Greenwood for his helpful comments and suggestions, and Mr.A.C.Thompson for his expert technical assistance.

\section{References}

Aviram, I. \& Krauss, Y. (1974) J. Biol. Chem. 249, 2575-2578

Boeri, E., Ehrenberg, K., Paul, K. G. \& Theorell, H. (1953) Biochim. Biophys. Acta 12, 273-282

Brunori, M., Wilson, M. T. \& Antonini, E. (1973) J. Biol. Chem. 247, 6076-6081

Fruton, J. S. \& Simmonds, S. (1963) General Biochemistry, 2nd edn., pp. 298-299, J. Wiley and Sons, New York

Harbury, H. A. \& Loach, P. A. (1960) J. Biol. Chem. 235, 3645-3653

Hawkridge, F. M. \& Kuwana, T. (1973) Anal. Chem. 45, 1021-1027

Kaminsky, S. \& Davison, A. J. (1969) Biochemistry 8, 4631-4637
Karlsson, C. \& Ohman, J. (1972) Application Note 16, LKB Produckter, Stockholm

Margoliash, E. (1954) Biochem. J. 56, 535-543

Minakami, S., Chitani, K. \& Ishikura, H. (1957) J. Biochem. (Tokyo) 44, 535-536

Myer, Y. P. (1968) Biochemistry 7, 765-776

Rodkey, F. L. \& Ball, E. G. (1950) J. Biol. Chem. 182, 17-28

Salemme, F. R., Krant, J. \& Kamen, M. D. (1973) J. Biol. Chem. 248, 7701-7716

Schejter, A. \& Aviram, I. (1969) Biochemistry 8, 149-153

Schejter, A. \& George, P. (1964) Biochemistry 3, 1045-1049

Schejter, A., Aviram, I. \& Sokolovsky, M. (1970) Biochemistry 9, 5118-5122

Skov, K. \& Williams, G. R. (1971) Can. J. Biochem. 49, 441-447

Sokolovsky, M., Aviram, I. \& Schejter, A. (1970) Biochemistry 9, 5113-5117

Sokolovsky, M., Riordan, J. F. \& Vallee, B. L. (1966) Biochemistry 5, 3583-3589

Stellwagen, E. (1967) J. Biol. Chem. 242, 602-606

Theorell, H. \& Âkesson, A. (1941a) J. Am. Chem. Soc. 63, 1804-1811

Theorell, H. \& Åkesson, Å. (1941b) J. Am. Chem. Soc. 63, 1812-1818

Tsou, C. L. (1951) Biochem. J. 49, 363-367

Wilson, M. T. (1970) Ph.D. Thesis, University of East Anglia

Zerner, M., Gouterman, M. \& Kobayashi, H. (1966) Theor. Chim. Acta (Berlin) 6, 363-400 